\title{
Prof. Luis Oro é o Novo Presidente da EuCheMS
}

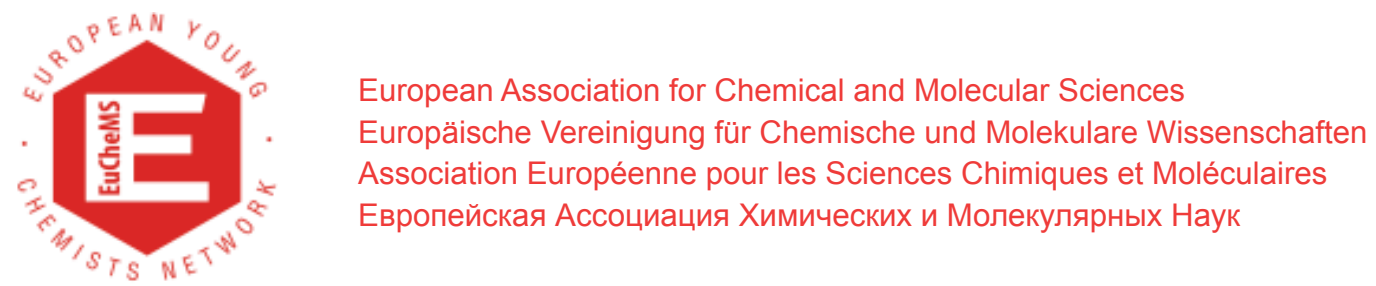

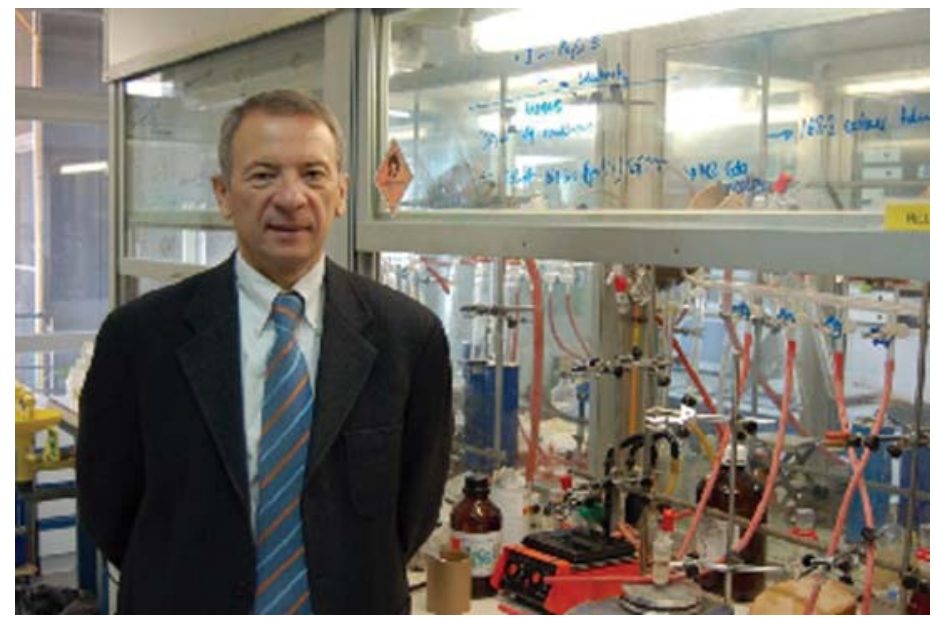

O Professor Luis Oro é, desde Outubro, o novo Presidente da EuCheMS, sucedendo ao Prof. Giovanni Natile. Doutorado em 1970 pela Universidade de Saragoça, Luis Oro é Professor de Química Inorgânica nessa Universidade e Director do Instituto Universi- tário de Catálise Homogénea (IUCH), tendo sido presidente da Real Sociedade Espanhola de Química de 2000 a 2005.

Os seus interesses científicos principais estão centrados na química de coordenação e organometálica dos metais do grupo da platina. É co-autor de mais de 500 artigos científicos sobre síntese, mecanismos reaccionais e catálise homogénea.

O Prof. Luis Oro deu uma contribuição importante para a renovação da Química, quer através da sua excelente contribuição científica quer pelas várias funções que desempenhou em Espanha e em organizações europeias, tendo sido Vice-Presidente da Fundação Europeia de Ciência (European Science Foundation), membro da Assembleia Europeia de Ciência e Tecnologia (ESTA), do Comité de Investigação Científica e Técnica (CREST) da UE e do Comité de Política Científica da OCDE.

\section{SHIC'08 - Solvay \& Hovione Ideas Challenge}

\section{Investigadores Portugueses Recebem Prémio de Inovação em Concurso Nacional}

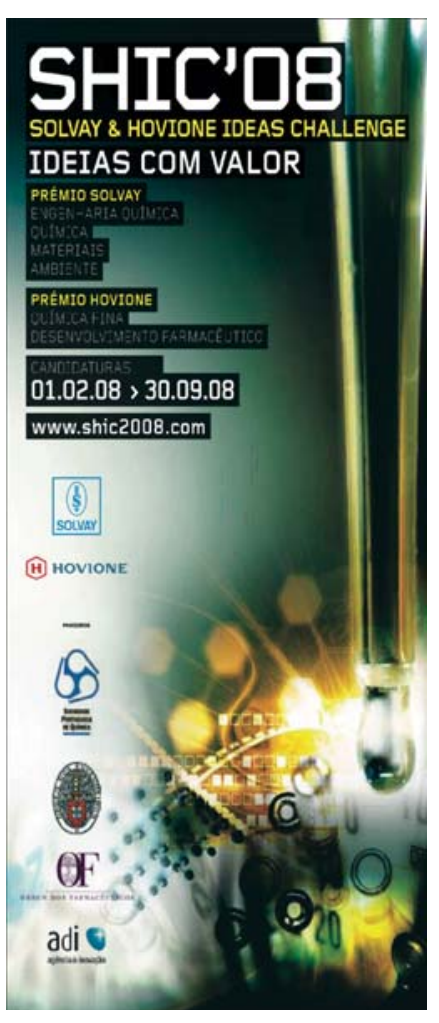

Em resposta à iniciativa SHIC'08 Solvay \& Hovione Ideas Challenge, divulgada no QUÍMICA 109 e apoiada pela SPQ, houve 81 projectos candidatos, no qual estiveram envolvidos 260 investigadores, docentes e estudantes universitários.

Os prémios SHIC'08 foram entregues, em parceria, pela SOLVAY PORTUGAL e HOVIONE, numa cerimónia de encerramento no passado dia 18 de Novembro no Museu do Oriente, onde foram revelados os vencedores dos dois prémios: Prémio Solvay, vocacionado para a área da engenharia química e ambiente, e Prémio Hovione, dirigido à química fina e desenvolvimento farmacêutico.

A cada projecto vencedor foi atribuído um prémio no valor de 10 mil euros, o qual tem como objectivo viabilizar a sua concretização.
O Prémio Solvay foi atribuído ao projecto "Produção de um novo biopolímero biodegradável com aproveitamento do glicerol", que apresenta, como novidade mundial, a possibilidade de transformar um resíduo do biodiesel num produto de valor acrescentado, já que se perspectiva a sua aplicação numa gama alargada de aplicações industriais, nomeadamente no sector alimentar e da cosmética, em substituição de produtos de custo mais elevado, como a goma de guar, alginatos e outros.

Uma mais-valia para o sector dos biocombustíveis e da sustentabilidade industrial, já que ao aumentar o período de vida útil de um resíduo se diminui o seu impacto no meio ambiente. Verificam-se igualmente relevantes benefícios ao nível da produção, que, por não estar dependente de condições climáticas ou sazonais, apresenta custos de 